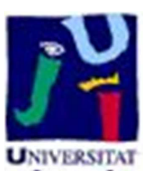

Título artículo / Títol article: Effects of network market orientation on new ventures' international performance

Autores / Autors

Diego Monferrer, Andreu Blesa, María Ripollés, Inés Kuster, Natalia Vila

Revista:

International Journal of Business Environment

Versión / Versió:

Versió pre-print

Cita bibliográfica / Cita bibliogràfica (ISO 690):

MONFERRER, Diego, et al. Effects of network market orientation on new ventures' international performance. International Journal of Business Environment, 2013, vol. 5, no 3, p. 268-298. 


\title{
Effects of network market orientation on new ventures' international performance
}

\author{
Diego Monferrer \\ Universitat Jaume I, Department of Business Administration and Marketing, Vicente Sos Baynat, s/n. 12071 \\ Castellón, Spain. E-mail: dmonferr@emp.uji.es.
}

\begin{abstract}
Andreu Blesa
Universitat Jaume I, Department of Business Administration and Marketing, Vicente Sos Baynat, s/n. 12071 Castellón, Spain. E-mail: blesa@emp.uji.es.

\section{María Ripollés}

Universitat Jaume I, Department of Business Administration and Marketing, Vicente Sos Baynat, s/n. 12071 Castellón, Spain. E-mail: mripolle@emp.uji.es.
\end{abstract}

\section{Inés Kuster}

Universitat de València, Department of Marketing, Avenida de los Naranjos, s/n. 46022 Valencia, Spain. E-mail: Ines.Kuster@uv.es.

\section{Natalia Vila}

Universitat de València, Department of Marketing, Avenida de los Naranjos, s/n. 46022 Valencia, Spain. E-mail: Natalia.Vila@uv.es

\section{Biographical notes:}

Diego Monferrer PhD is Associate Professor of Marketing in the Department of Business Administration and Marketing at Universitat Jaume I (Spain). His research interests include market orientation, networking, born globals, international marketing and the marketing/entrepreneurship interface. He has published articles in journals such as International Business Review; Journal of International Entrepreneurship; Investigaciones Económicas; World Review of Entrepreneurship, Management and Sustainable Development; International Journal of Technology Transfer and Commercialisation, and has presented papers at several conferences, such as European Conference on Entrepreneurship and Innovation; Research in Entrepreneurship and Small Business; European Marketing Academy Conference; Academy of Marketing Science World Marketing Congress; International Network of Business and Management Journals; International Congress on Marketing Trends.

Andreu Blesa $\mathrm{PhD}$ is Associate Professor of Marketing in the Department of Business Administration and Marketing at Universitat Jaume I (Spain). His research interests include market orientation, networking, relationship marketing, and the marketing/entrepreneurship interface. He has published articles in journals such as Journal of World Business; International Business Review; International Marketing Review; Annals of Tourism; Journal of Entrepreneurship; International Journal of Retail and Distribution Management; European Journal of Marketing; International Journal of Entrepreneurship and Innovation; Investigaciones Económicas, and has presented papers at several conferences, such as the Academy of Marketing Science; European Marketing Academy; Research in Entrepreneurship and Small Business; the European Conference on Entrepreneurship and Innovation.

María Ripollés PhD is Associate Professor of Management in the Department of Business Administration and Marketing at Universitat Jaume I (Spain). Her research interests include entrepreneurial orientation, firms' internationalization processes, foreign entry modes and international entrepreneurship. She has published articles in journals such as Journal of World Business, International Business Review; International Marketing Review; Journal of Entrepreneurship; International Journal of Entrepreneurship and Innovation; Journal of International Entrepreneurship; Investigaciones Económicas, and has presented papers at several conferences, such as the European International Business Academy Conference; the European Academy of Management Conference; the European Marketing Academy; Research in Entrepreneurship and Small Business; the European Conference on Entrepreneurship and Innovation. 
Natalia Vila PhD is Professor of Marketing in the Department of Marketing at University of Valencia (Spain). Her research interests include strategic marketing, brand positioning and international marketing, She has published articles in journals such as Information \& Management; European Journal of Marketing; International Marketing Review; Marketing Intelligence and Planning; Journal of Consumer Marketing; Innovation: Management, Policy and Practice; Journal of Food Products Marketing; Journal of Relationship Marketing; Innovative Marketing; Journal of Marketing Management; Journal of Strategic Marketing; European Journal of Innovation Management; Qualitative Market Research: An International Journal; Journal of Euromarketing; The Marketing Review; Journal of Global Marketing; Journal of Travel and Transport Marketing; Sex Roles, Equal Opportunites International, Journal of Teaching in International Business; Neural Computing \& Applications, Micro \& Macro Marketing, Multicultural Education \& Technology Journal, Tourism Economics and Spanish refereed journals. She has presented papers at several conferences, such as the Academy of Marketing Science or European Marketing Academy among others.

Inés Kuster PhD is Professor of Marketing in the Department of Marketing at University of Valencia (Spain). Her research attention has focused on the areas of strategic marketing and sales. She has published articles in several refereed journals such as Annals of Tourism Research; European Journal of Marketing; JQRM; European Journal of Innovation Management; Qualitative Market Research: An International Journal; The Marketing Review; Marketing Intelligence and Planning; Journal of Relationship Marketing; Asia Pacific Journal of Marketing and relevant Spanish journals. She is author of diverse books, and book chapters related to her investigation field. She has also presented papers at the European Marketing Conference and the Academy of Marketing Conference. She collaborates with several companies, helping them in marketing areas (recruiting salespeople, training sales managers, analysing commercial efforts, etc.).

\begin{abstract}
:
By combining international entrepreneurship and marketing aspects, this work attempts to emphasise the importance of relational knowledge in international new ventures by studying the influence of network market orientation on the international results obtained by these firms. The results obtained in the comparison with the proposed structural equations model confirm that network market orientation is a determining factor for firms to achieve better international results. This influence is observed both directly and indirectly with the mediating effect on the differentiation- and cost-based competitive advantages developed by INVs.
\end{abstract}

\title{
Keywords:
}

Network market orientation; international performance; competitive advantages; international new ventures; international entrepreneurship.

\section{Introduction}

The majority of previous research on internationalisation behaviour concludes that firms become involved in international markets gradually (Johanson and Vahlne, 1977). However in the last 15 years, a new kind of business has emerged that does not follow a gradual internationalisation pattern, but is characterised by rapid commitment to international activity. Oviatt and McDougall (1994) called these firms "international new ventures" (INVs) and defined them as "business organizations that, from inception, seek to derive significant competitive advantage from the use of resources and the sale of outputs in multiple countries" (Oviatt and McDougall, 1994: 470). So they are entrepreneurial firms that exhibit an international orientation derived from early entry in foreign markets.

The work of Oviatt and McDougall has given rise to a new line of research known as international entrepreneurship that centres on the study of how new ventures are committed to developing processes of discovery, enactment, evaluation, and exploitation of opportunities across national borders to create future goods and services (Oviatt and McDougall, 2005). Since Oviatt and McDougall's (1994) seminal article, study of the factors that could encourage early international behavior in new firms has attracted the attention of many researchers in the fields of entrepreneurship, internationalization and marketing (see Aspelund, Madsen and Moen, 2007; Etemad, 2003; Rialp, Rialp and Knight, 2005 or 
Zahra and George, 2002 for a review). All these studies have significantly contributed to our understanding of the reasons that drive early internationalization in these firms.

Past research in this area has centred on determining factors that may explain the exceptional speed with which certain new ventures can internationalise (Oviatt and McDougall, 2005; Rialp, Rialp and Salas, 2002; Rialp, Rialp and Knight, 2005; Westhead, et al., 2001; Zahra and Garvis, 2000; Zahra and George, 2002). However, Autio (2005) and Zahra (2005) consider that to be able to advance in our understanding of INVs, we need to analyse the factors that can affect these firms' competitiveness and results after their creation phase, particularly from a marketing perspective (Aspelund, Madsen and Moen, 2007; Casillas et al., 2009; Ha-Brookshire and Dyer, 2009; Rialp, Rialp and Knight, 2005).

Different studies assign a key role to market knowledge in the international progress made by new ventures in that it constitutes a key variable for proactively seeking international opportunities (Acedo and Jones, 2007; Autio, Sapienza and Almeida, 2000; Brennan and Garvey, 2009; Casillas et al., 2009; Gassman and Keupp, 2007; Jantunen et al., 2008; Knight and Cavusgil, 2004; Liao, Chang and Wu, 2010; Liao et al., 2011; Nordman and Melen, 2008; Perks and Hughes, 2008; Sapienza et al., 2006; Weerawardena et al., 2007; Zhou, 2007). In fact, market knowledge has been considered one of the main impediments that small businesses have to overcome in their internationalisation process (Johanson and Vahlne, 1977; Loane and Bell, 2006).

If we focus on attempting to identify the main source generating this knowledge, we observe that traditional gradualist models play a key role in knowledge generation and, therefore, in the internationalisation process, towards the firm's experience (at home and abroad) (Johanson and Valhne, 1977). However in the case of INVs, knowledge based on experience cannot be considered the only source of the foreign markets knowledge used by these firms as their experience, due to their young age, is minimal (Burgel and Murray, 2000). For this reason, it is necessary to investigate the way in which INVs manage to acquire and interpret information about markets, and how they translate it into specific actions that affect the development of skills which contribute to maintaining their dynamism in international markets (Knight and Liesch, 2002).

In line with this, the marketing literature assumes that market orientation not only provides the information and knowledge that these businesses need to be competitive in turbulent environments, but also favours the integration of that information into the firm, thereby influencing its actions (Cadogan, Cui and Yeung, 2003; Bhuian, Menguc and Bell, 2005; Knight and Cavusgil, 2004; Qiu, 2008). In addition, and based on the social perspective, the study of entrepreneurship has also highlighted the importance of the links that entrepreneurs develop with members of their networks, regardless of them being customers, suppliers, distributors, family members or other private or public institutions, as these can be crucial in capturing a larger quantity of more varied information about new market trends and opportunities, the way of exploiting these opportunities and the way of accessing the resources required to do this (Chetty and Blankenburg, 2000; Coviello, 2006; Etemad, 2003; Gabrielsson et al., 2008; Gilmore, Carson and Rocks, 2006; Hite and Hesterly, 2001; Johanson and Vahlne, 2009; Kiss and Danis, 2008; Loane and Bell, 2006; Ojala, 2009; Perks and Hughes, 2008; Sharma and Blomstermo, 2003). However, little is known about the mechanisms and ways that would allow INVs to acquire knowledge through their networks (Coviello, 2006; Loane and Bell, 2006).

When we jointly analyse market orientation and belonging to networks of firms as possible determining factors of competitiveness and INVs' results thanks to their contribution to market knowledge generation and management, we realize that both these factors seem to be related. In fact, the dynamics which generates belonging to a network of firms is closely related with the knowledge generation process for the firm. Indeed, one of the immediate advantages of a firm's activity within a network of firms is gaining access to a huge amount of information and additional knowledge which is difficult to achieve if acting individually (Johnson and Sohi, 2003; Zucchella, Palamara and Denicolai, 2007). In this way, the firms in the network use their relations to gain access to new knowledge by sharing it with other firms among which there is a climate of trust. Therefore, and particularly with new ventures which are struggling to establish credibility in their markets, networks can become an important source of knowledge. Despite both factors apparently complementing each other well from the theoretical perspective, very little is known about how they are combined (Evanschitzky, 2007; 
Helfert, Ritter and Walter, 2002; Langerak, 2001). Hence, it is necessary to study the mechanisms and routines by which INVs can acquire knowledge through their networks (Loane and Bell, 2006; Hyvönen and Tuominen, 2007), and how they influence these ventures' competitiveness and results (Evanschitzky, 2007). Specifically, given the lack of studies that jointly analyse the adoption of market orientation and belonging to a network of firms (Hyvönen and Tuominen, 2007) at the international level, this work focuses on Spanish INVs context and includes the complementariness between both factors in a single construct called network market orientation.

In order to meet this objective, the theoretical frame is firstly presented, which helps define network market orientation and also helps formulate hypotheses on its influence on INVs' international results. Afterwards, the empirical study carried out to check the hypothesis model is provided by analysing the results obtained and the main conclusions drawn from them. Finally, limitations and future research lines associated with this study are described.

\section{Network market orientation}

Past research has defined different types of business networks according to different dimensions: actors intervening in the network, network activities, and the resources exchanged between network actors through the activities that are carried out (Karlsson, 2003). Following this tradition, this study defines a network as a system of agents (which must be businesses) connected by a set of relationships and activities through which the various agents exchange different types of resources. There must be at least three companies (Bouncken, 2003) and there must be an egocentric networks as a central company is taken as the reference (Borgatti and Foster, 2003; Hite and Hesterly, 2001; Powell and Smith-Doerr, 2003). Indirect or second order links that the company is connected to through its direct relations are not included (Hite and Hesterly, 2001).

Starting from this characterization of the network concept we observe that the network market orientation construct originates from two different aspects. On the one hand, several authors have attempted to introduce the relational component into the traditional theoretical basis of firms' strategic orientation. Based on the consideration that relational marketing implies that "the firm is proactively involved in the creation, development and maintenance of committed, interactive and beneficial exchanges with certain agents of interest" (Harker, 1999: 16), several researchers have used the "relational marketing orientation" concept to refer to firms adopting a strategic focal point which promotes such performance (Sin et al., 2002, 2005; Tse et al., 2004). On the other hand, some authors have incorporated the knowledge-based approach into this relational vision by attempting to apply market orientation concept used in the firm's domain in a network context (Elg, 2002, 2003; Evanschitzky, 2007; Helfert, Ritter and Walter, 2002; Langerak, 2001; Siguaw, Simpson and Baker, 1999).

Nevertheless, this initial reference to the network market orientation concept is not really based on the network, instead the authors suggest that network market orientation is the result of summing individual members' market orientations (Beverland and Lindgreen, 2007; Chung, Jin and Sternquist, 2007; Hyvönen and Tuominen, 2007; Siguaw, Simpson and Baker, 1999). Along these lines, Siguaw, Simpson and Baker (1999) consider that the supplier's market orientation influences the distributor's market orientation to the extent that distribution channel market orientation is the sum of all its members' individual activities. In a study that focuses on the Korean department store industry, Chung, Jin and Sternquist (2007) point out that the retailers' market orientation has a positive influence on their suppliers' market orientation.

In relation to the previous approach, Elg's work (2002) is a actually change of perspective as it contemplates market orientation adopted jointly by several firms rather than it being the sum of individual firms' market orientations. Based on the three behavioural components in Kohli and Jaworski's (1990) approach, Elg (2002) defines network market orientation as the activities carried out jointly by two or more independent firms to create a network or an individual relationship that is more sensitive to market demands. In this way, market orientation involves the generation and dissemination of, and response to, market information. In particular, according to Elg (2002), information generation in the network refers to marketing activities in collaboration with various firms 
in the network which provide information about their customers and the market in general. Information is disseminated among network members when, for example, network members exchange and informally share the information obtained. Finally, the collective response occurs when the businesses participating in the network coordinate their activities to design and start up a response that enables them to better address consumer needs. However, this proposal has also been criticised insofar as it is merely an adaptation of the market orientation concept in the individual firm's area and that it does not reflect the specific mechanisms that are characteristic of the network (Helfert, Ritter and Walter, 2002; Lin and Chen, 2006).

In response to the limitations of the above proposals, Helfert, Ritter and Walter (2002) present a conceptualisation of network market orientation which is not limited to simply applying the dimensions of the market orientation construct to the global network. As an alternative, Helfert, Ritter and Walter (2002) propose a theoretical model that identifies the processes and basic mechanisms associated with relationship knowledge management which characterises market orientation in a network context. In particular, Helfert, Ritter and Walter (2002) identify four major relationship management areas: exchange, coordination, conflict resolution and adaptation.

Exchange processes serve the needs and requirements of other network members. There are exchange activities concerning products/services; exchanges of information relating to product specifications, logistics, delivery or payment problems, special offers or orders, and to establishing mid-term forecasts of the opportunities, needs and mutual requirements between parties. Coordination activities refer to the synchronisation of the relations among members. They are required when there is more than one member in the organisational process, and involve the establishment, use and control of formal rules and procedures, and the execution of informal influences. Constructive mechanisms for conflict resolution are more than just coordination between parties as they refer to extraordinary, nonstandard situations which may occur in lasting relations. Adaptation activities become necessary in relations with customers to address a network member's special needs or abilities. They can apply to different areas: products/services, manufacturing processes, logistics, delivery/payment methods, employees' qualifications, or terms and conditions of product use.

By summarising the different arguments presented in this work, network market orientation is defined as "a strategic orientation established jointly by the different members in the business relations network which involves, in a climate of trust, collaboration and commitment, engaging in certain activities and fundamental shared behaviours (adaptation, coordination, conflict resolution and exchange) based on the generation of an extended intellectual capital (which includes social capital) in order to increase the competitiveness of the network and its individual members in an attempt to provide superior value to end customers by satisfying their needs" (see Figure 1).

Figure 1: Network market orientation

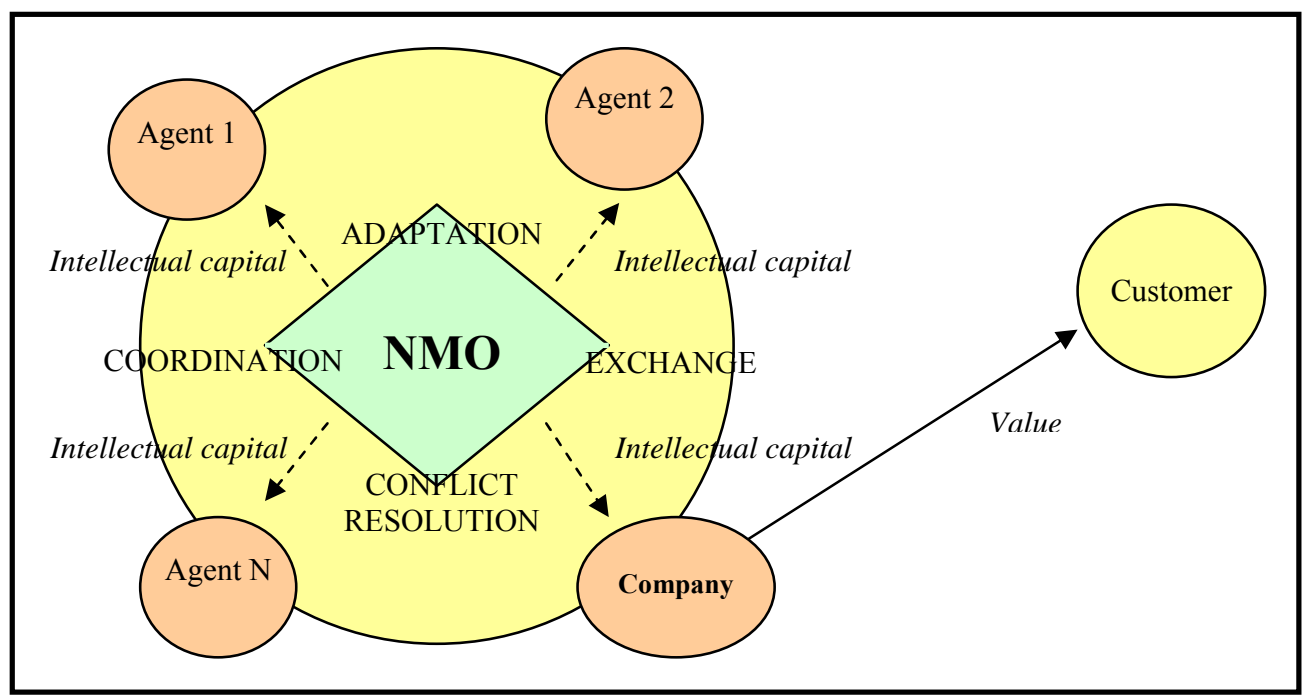




\section{Network market orientation and INV's international performance}

\subsection{Direct effect}

The positive effect of market orientation on business results has been demonstrated in a range of contexts, such as large- and medium-sized firms, in profit-making and non-profit-making organisations, in industrialised and developing economies, as meta-analyses of recent years have shown (Cano, Carrillat and Jaramillo, 2004; Grinstein, 2008; Kirca, Jayachandran and Bearden, 2005; Shoham et al., 2005). These studies share the conviction that access to unique knowledge is one of the firms' most valuable assets to obtain superior results (Liebeskind, 1996; Penrose, 1959; Qiu, 2008) because it provides them of a panoramic vision of the competitive sphere by keeping them informed about customers' demand, customers' underlying purchasing desires, technological advances, economic situations and their rivals' competitive actions (Qiu, 2008).

However, given their limited experience, INVs can encounter difficulties when accessing certain sources of knowledge (Li et al., 2008). It is for this very reason that many firms decide to rely on the relations established in their network to overcome these limitations. In this way, knowledge, organisational capacities, financial resources and other key psychic resources, equipment become available to them in terms of their results, which they would not have had access to if they had acted on an their own as individuals (Johnson and Sohi, 2003; Racela, Chaikittisilpa and Thoumrungroje, 2007; Zucchella, Palamara and Denicolai, 2007). Thanks to network market orientation, INVs benefit from certain positive knowledge-based elements that improve their results. Indeed, this network orientation helps build trust among network members, which turns into more effective relational learning (Selnes and Sallis, 2003). According to Lado, Boyd and Hanlon (1997), this climate of trust reduces uncertainty, acts as a social control mechanism and as an integrating mechanism that cuts the transaction costs destined to safeguard against risks associated with the other network members' opportunism, thus leading to the reciprocity of an open commitment between parties during exchange processes. All these aspects favour a firm's success.

Therefore, the basis to understand the network market orientation effect on the results in INVs lies in increased efficiency and efficacy when opting for organised knowledge management. Thus it is necessary to assess not only the various firms making up the network, but also the firm's functional areas with their different objectives. Network market orientation provides all these agents with the tools they need to combine their objectives, which enhances the efficacy of their actions (Meso and Smith, 2000; Offsey, 1997; Sher and Lee, 2004). Therefore, the following hypothesis is put forward:

\section{$H_{1}$. Greater market orientation in the INV network leads to the achievement of better international performance.}

\subsection{Indirect effect through competitive advantages}

Just as there are works which defend the direct relation between market orientation and international results, a growing number of researchers acknowledge that there are still doubts as to the way this influence arises. So it is fundamental to develop more complex models that study the possible factors mediating in this relation in more depth (Baker and Sinkula, 2005; Beverland and Lindgreen, 2007; Elg, 2007; Ellis, 2006; Han, Kim and Srivastava, 1998; Hult and Ketchen, 2001; Hunt and Lambe, 2000; Hyvönen and Tuominen, 2007; Langerak, 2003; Langerak, Hultink and Robben, 2007; Li et al., 2008; Matsuno, Mentzer and Rentz, 2004; Menguc, Auh and Shih, 2007; Noble, Sinha and Kumar, 2002; O'Cass and Ngo, 2007; Snoj, Milfelner and Gabrijan, 2007). With this in mind, this work considers, in line with other former studies (Ha-Brookshire and Dyer, 2009; Ling-yee and Ogunmokun, 2001; Morgan, Kaleka and Katsikeas, 2004; Piercy, Kaleka and Katsikeas, 1998), that firms' generation of superior results is hard to understand without them achieving competitive advantages.

When it comes to specifying these competitive advantages, we count on the work of Porter (1985), who considers that the different meanings used to refer to competitive advantages boil down to two general ones into which all the rest fit (Ha-Brookshire and Dyer, 2009; Ling-yee and Ogunmokun, 2001; Morgan, Kaleka and Katsikeas, 2004): product differentiation-based and cost-based competitive 
advantages. The former refer to factors such as quality, design and other attributes which distinguish firms' offers of value if compared to those of their rivals (Morgan, Kaleka and Katsikeas, 2004; Porter, 1985), as well as advantages linked to services such as delivery speed, reliability and managing additional services (Cavusgil and Zou, 1994; Ha-Brookshire and Dyer, 2009; Morgan, Kaleka and Katsikeas, 2004; Piercy, Kaleka and Katsikeas, 1998). However, cost-based advantages lie in the domain of manufacturing, administration and commercialisation costs. They offer the producer value in the form of lower costs and they offer the consumer the lowest price (Ha-Brookshire and Dyer, 2009; Kotha and Nair, 1995; Morgan, Kaleka and Katsikeas, 2004; Porter, 1985).

When we centre on the influence that network market orientation has on these advantages, Sher and Lee (2004) provide several arguments that back this relation. Firstly, Sher and Lee (2004) indicate that promoting information exchange, as it occurs in network market orientation, leads to employees facing similar decisions, which facilitates learning and allows them to respond to changes taking place in the workplace more quickly and with less costs. Secondly, and thanks to the mechanisms set up to manage relational knowledge, network members can identify ways of improving quality, reliability and speed with which information and knowledge are shared (Chen, Lin and Chang, 2009), meaning that they act more competitively in their markets and they maximise the returns deriving from these markets. Thirdly, establishing knowledge management, not at an individual level, but by considering the different agents making up the firm's network, permits the firm to access valuable information about markets from different domains and perspectives, which has a positive effect on its competitiveness and on the strength of its actions (Sher and Lee, 2004). For instance, the firm can develop products of greater value thanks to it possessing more complete information about its customers. Besides, access to information about its suppliers allows the firm to select the best components in terms of quality and/or costs and the most qualified suppliers. Sher and Lee (2004) even indicate that the firm may obtain knowledge from establishing horizontal collaborations which enable it to use its competitors' routines. The more available the information and the greater the diversity of its sources, the easier it is to develop a more distinguishable offer and/or at a lower cost than the competitors' offer. All these elements can be considered elements that promote more lasting advantages because, as they are based on intimate relations, they are more difficult to manage, understand, copy or counteract (Day, 2000; Day and Van den Bulte, 2002; Dyer and Singh, 1998; Jarratt, 2004). Based on it, we propose that:

$\mathrm{H}_{2}$. Greater market orientation in the INV network offers more differentiation-based competitive advantages.

$\mathrm{H}_{3}$. Greater market orientation in the INV network may lead to the greater development of costbased competitive advantages.

The role of competitive advantages on the results obtained by firms has been broadly discussed (Barney, 1991; Cavusgil and Zou, 1994; Day and Wensley, 1988; Ha-Brookshire and Dyer, 2009; Hunt, 2000; Katsikeas, 1994; Ling-yee and Ogunmokun, 2001; Mizik and Jacobson, 2003; Moen, 1999; Morgan, Kaleka and Katsikeas, 2004; Piercy, Kaleka and Katsikeas, 1998; Snoj, Milfelner and Gabrijan, 2007; Srivastava, Fahey and Christensen, 2001; Sudharshan and Sánchez, 1998). When we review the conceptualisations of the competitive advantage concept, we can see, by definition, that a firm has a competitive advantage over another firm when it obtains a superior result (Day and Wensley, 1988; Grant, 1996). Therefore, the competitive advantage can be seen as a direct background of new venture' international result because the superiority that relates to their attempt to offer value determines the purchasing performance of its target market (Anderson, Häkansson and Johanson, 1994; Piercy, Kaleka and Katsikeas, 1998), and consequently its result (Cavusgil and Zou, 1994; Day and Wensley, 1988; Mizik and Jakobson, 2003; Morgan, Kaleka and Katsikeas, 2004; Snoj, Milfelner and Gabrijan, 2007; Srivastava, Fahey and Christensen, 2001; Sudharshan and Sánchez, 1998). When a firm has competitive advantages (regardless of them being differentiation-based and/or cost-based ones) and is, therefore, capable of offering higher value to its customers, the satisfaction and loyalty of these customers, and the firm's market share and trading volume increase, whereas the costs required to attend to and serve these customers lower (Mizik and Jakobson, 2003; Reichheld, 1993). As Snoj, Milfelner and Gabrijan (2007, p. 153) point out, "sustaining competitive advantages is the basis for achieving a superior business result, survival and development". Therefore, the following are proposed: 
$\mathrm{H}_{4}$ : INVs' development of differentiation-based competitive advantages leads to the achievement of better international performance.

$H_{5}$. INVs' development of cost-based competitive advantages leads to the achievement of better international performance.

Figure 2 shows the model for the analysis.

Figure 2: Model of the impact of network market orientation on INVs' international performance

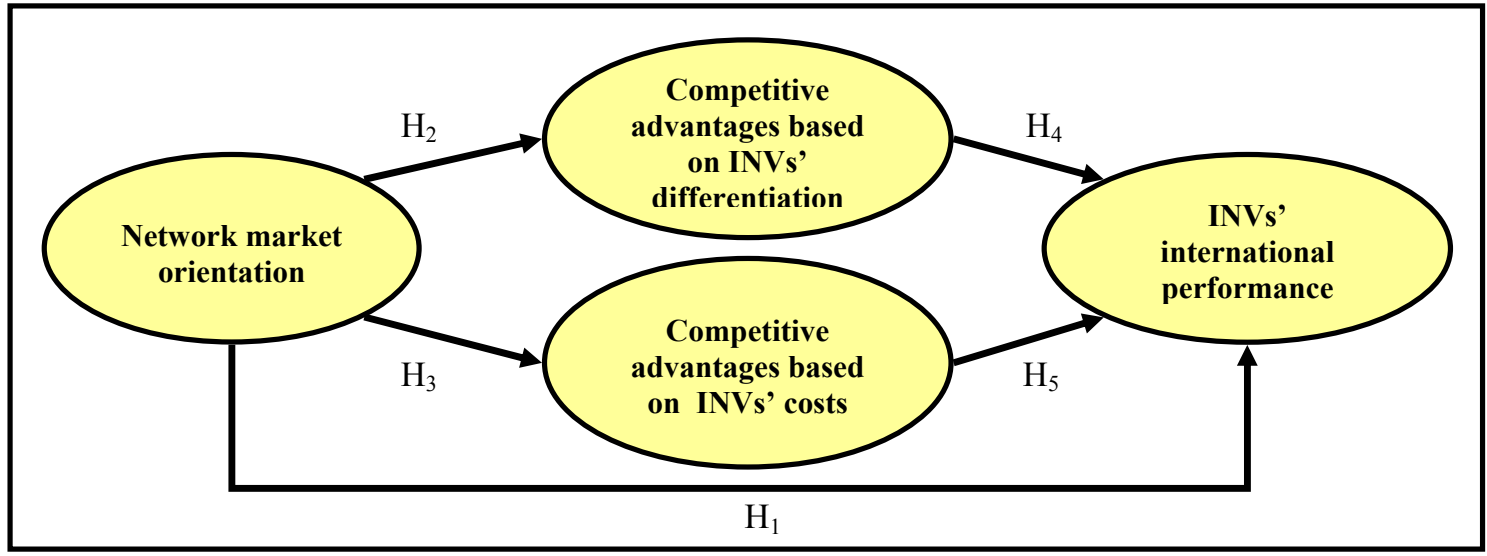

\section{Methodology}

\subsection{Sample selection and information collection}

The hypotheses posited in this work were tested in a total of 2,012 firms with international activity founded after 2005. Contact data were obtained from the Dun and Bradstreet and SABI databases. In an attempt to make the results more generalisable, the study includes firms from very different sectors. In order to purge this database and to ensure that the firms chosen for the study have the characteristics required to be considered INVs, the following criteria or selection filters were applied: (1) ventures were created after 2005 to ensure that they were new; (2) they had international activity in the first three years since their creation, indicating that they were firms that dealt with foreign markets immediately; (3) a minimum of $25 \%$ of their annual sales were overseas sales, evidencing consolidated international presence; (4) ventures made their own strategic decisions so that subsidiaries or affiliates were rejected; (5) ventures had at least three employees, thus rejecting the self-employed model with one or two employees; (6) they formed part of a network of firms with a minimum of three members, a necessary criterion if we take into account the aim of this research. After the purging process, the total dropped to 1,023 firms with theoretical representativeness.

Fieldwork involved the production of an online questionnaire. The sampling process took place between September 2009 and July 2010, and provided a total of 303 valid responses with a response rate of $29.62 \%$ of the total population.

The data enabled the analysis of the main characteristics of the sample object of this study (see Table 1). INVs were mostly SMEs from the industrial sector (61.2\%), including the food and agriculture, metal and textile industries. The commercial sector was represented by $31.6 \%$, including firms that export and import products relating to the above-cited industrial sectors. Finally, a smaller percentage $(7.2 \%)$ of INVs were from the services sector and included mostly financial, tourism and communication agencies.

The average number of employees in these INVs was 28.55 , and $75 \%$ of the firms interviewed had less than 25 employees. As regards foreign activity, although the average percentage of activity carried out by these INVs abroad was $17.63 \%$, when considering all the activities in the value chain, it should be noted that the value associated with commercialisation work was $41.50 \%$. By contemplating the fact that INVs' commercial activity was directly related to sales, this figure can serve as a reference when valuing the percentage of sales that INVs make abroad, which was clearly over the $25 \%$ limit required for the sample selection criterion. 
The average age of these firms was 3.90 years. Regardless of the year of their creation, the descriptive and frequency analyses show that INVs were created with a clear international vocation as their international activity began, on average, 0.28 years after their creation. In fact, $76.6 \%$ of the INVs interviewed started their international activity immediately after their creation.

Table 1: General characteristics of the INVs

\begin{tabular}{|c|c|c|c|c|c|c|c|}
\hline \multicolumn{2}{|c|}{$\begin{array}{c}\text { Years since creation to } \\
\text { the starting } \\
\text { international activity } \\
\text { in }\end{array}$} & \multicolumn{2}{|c|}{$\begin{array}{l}\text { Total number of } \\
\text { employees }\end{array}$} & \multicolumn{2}{|c|}{$\begin{array}{l}\text { International activities in the value } \\
\text { chain }^{2}\end{array}$} & \multicolumn{2}{|c|}{ Activity sector } \\
\hline Years elapsed & $\%$ & Employees & $\%$ & Activity & Average \% & Sector & $\%$ \\
\hline 0 & 76.6 & 5 or under & 26.4 & Manufacturing process & 11.58 & \multirow{2}{*}{ Industrial } & \multirow{2}{*}{61.2} \\
\hline 1 & 19.8 & $6-11$ & 25.4 & Research and Development & 7.40 & & \\
\hline 2 & 2.1 & $12-25$ & 23.8 & Commercialisation & 41.50 & \multirow{2}{*}{ Commercial } & \multirow{2}{*}{31.6} \\
\hline 3 & 1.6 & Over 25 & 24.4 & Advertising and promotion & 11.18 & & \\
\hline \multirow{2}{*}{\multicolumn{2}{|c|}{$\begin{array}{c}\text { Average years elapsed }= \\
0.28\end{array}$}} & \multirow{2}{*}{\multicolumn{2}{|c|}{$\begin{array}{c}\text { Average employees }= \\
\mathbf{2 8 . 5 5}\end{array}$}} & After-sales service & 16.51 & \multirow{2}{*}{ Services } & \multirow{2}{*}{7.2} \\
\hline & & & & Average international acti & $y=17.63$ & & \\
\hline
\end{tabular}

${ }^{1}$ The figure corresponds to the difference between 2010 and the date the venture was founded.

${ }^{2}$ Figures expressed as a percentage of total responses.

By taking into account the general characteristics of the networks to which the firms in our study belonged (see Table 2), we can see that they joined a network practically from the time they were created. In fact, $82.4 \%$ joined immediately. After the first year, the percentage of firms already in a network had risen to $96.4 \%$.

These networks usually contained a small number of firms, an average of 5.81 firms. Over $50 \%$ of the networks to which the INVs in this survey belonged were formed by three firms. These firms were usually located near the business itself, with $62.29 \%$ of networks covering a self-governing region. Finally as regards the nature of these networks, the main objective set by the firms in the network when establishing their relations was related to commercialising their products. The networks of $92.5 \%$ of the INVs interviewed were marketing networks. A considerably lower percentage of around $15 \%$ corresponded to technological and market networks, where members shared specific systems and technological processes, or offered products and services similar to these market segments.

Table 2: General characteristics of the main networks of the studied INVs

\begin{tabular}{|c|c|c|c|c|c|c|c|}
\hline \multicolumn{2}{|c|}{$\begin{array}{l}\text { Years since creation to } \\
\text { entrance in the network }\end{array}$} & \multicolumn{2}{|c|}{ Network size } & \multicolumn{2}{|c|}{$\begin{array}{l}\text { Geographical scope of } \\
\text { the network }\end{array}$} & \multicolumn{2}{|l|}{ Type of network } \\
\hline Years elapsed & $\%$ & Firms & $\%$ & Scope & $\%$ & Type & $\%$ \\
\hline 0 & 82.4 & 3 & 55.6 & \multirow{2}{*}{$\begin{array}{l}\text { Self-governing } \\
\text { region }\end{array}$} & \multirow{2}{*}{62.19} & Social network & 2.5 \\
\hline 1 & 13.5 & $4-5$ & 19.4 & & & Technological network & 14.9 \\
\hline 2 & 1.4 & $6-10$ & 11.1 & \multirow{2}{*}{ National } & \multirow{2}{*}{15.42} & Institutional network & 2.0 \\
\hline 3 & 2.7 & $>10$ & 13.9 & & & Infrastructure network & 5.5 \\
\hline \multirow{2}{*}{\multicolumn{2}{|c|}{$\begin{array}{c}\text { Average years elapsed }= \\
0.12\end{array}$}} & \multirow{2}{*}{\multicolumn{2}{|c|}{$\begin{array}{c}\text { Average firms }= \\
5.81\end{array}$}} & \multirow{2}{*}{ International } & \multirow{2}{*}{22.39} & Marketing network & 92.5 \\
\hline & & & & & & Market network & 15.4 \\
\hline
\end{tabular}

${ }^{1}$ According to the location of most network members.

\subsection{Measurement instruments}

Network market orientation was measured after adapting the scale proposed by Helfert, Ritter and Walter (2002). These authors offer the construct measurement by using the following as a reference: relational management activities that define network market orientation in 12 items spread out over the following four dimensions (see Table 3 ): connection ( 2 items), adaptation (3 items) conflict resolution (3 items) and exchange (4 items).

Table 3: The network market orientation measurement scale ADAPTATION

Extent to which the firms in my main relations network...

1. ...update our offerings to customer needs. (ADAP.1)

2. ...update product distribution to customer demands. (ADAP.2) 


\begin{tabular}{|c|}
\hline COORDINATION \\
\hline $\begin{array}{l}\text { 3. } \quad \text {...discuss each member's tasks in collaboration with the customer. (COOR.1) } \\
\text { 4. } . \text {... ensure that the commitments agreed by both parties are fulfilled. (COOR.2) } \\
\text { 5. ...discuss the steps required to achieve the network's joint objectives. (COOR.3) }\end{array}$ \\
\hline CONFLICT RESOLUTION \\
\hline $\begin{array}{l}\text { 6. ...when there are conflicts, we try to impose our individual interests at all costs. (CONF.1) }{ }^{1} \\
\text { 7. ...when there is a conflict, we wait for the situation to calm down through simple inertia. (CONF.2) }{ }^{1} \\
\text { 8. } \\
\text {...when there is a conflict, we try to reach an acceptable compromise for all parties. (CONF.3) }\end{array}$ \\
\hline EXCHANGE \\
\hline $\begin{array}{l}\text { 9. ...we engage in shared learning about specific customer needs. (EXCH.1) } \\
\text { 10. ...we exchange information to act quickly in the event of customer problems with the products or services we } \\
\text { offer. (EXCH.2) } \\
\text { 11. ...we exchange knowledge in order to improve our offers to customers. (EXCH.3) } \\
\text { 12. ...we jointly develop solutions for these customers. (EXCH.4) }\end{array}$ \\
\hline
\end{tabular}

Source: Helfert, Ritter and Walter (2002). ${ }^{1}$ Reverted indicators.

As regards the measurement of competitive advantages, the work by Porter (1985) is still, even today, a model for defining the generic types of competitive advantages that a firm can achieve (HaBrookshire and Dyer, 2009; Ling-yee and Ogunmokun, 2001; Morgan, Kaleka and Katsikeas, 2004): cost-based competitive advantages and product or service differentiation-based competitive advantages. The use and validity of these types are the still best demonstration of the solidity of Porter's (1985) proposal 25 years after they appeared in academia and research.

By taking this idea as a reference, Ling-yee and Ogunmokun (2001) offer a robust measurement scale generalised to the competitive advantages interpreted conceptually from the international marketing theory context. The present work redefines this scale by considering the proposals made by Morgan, Kaleka and Katsikeas (2004) and Ha-Brookshire and Dyer (2009). The scale is a 7-item 5-point Likert scale $(1=$ very inferior or worst situated; $5=$ very superior or leader $)$ reflecting the firm's position in relation to competition in terms of product differentiation (4 items) and costs ( 3 items) when adapting its offer to international market needs (Table 4).

Table 4: Measurement scales for competitive advantages

\begin{tabular}{|ll|}
\hline \multicolumn{1}{|c|}{ COMPETITIVE ADVANTAGES IN PRODUCT DIFFERENTIATION } \\
\hline 1. & Unique product design. (DIFCA.1) \\
2. & Creation of a distinctive image for its products. (DIFCA.2) \\
3. & After-sales service and/or technological support. (DIFCA.3) \\
4. & Development of higher quality products at comparable prices. (DIFCA.4) \\
\hline \multicolumn{1}{c|}{ COMPETITIVE ADVANTAGES IN COSTS } \\
\hline 1. & Lower cost of raw materials. (COSTCA.1) \\
2. & Lower unit production cost. (COSTCA.2) \\
3. & Lower prices than the competition. (COSTCA.3) \\
Source: Based on Ha-Brookshire and Dyer (2009), Ling-yee and Ogunmokun (2001) and Morgan, Kaleka and \\
Katsikeas (2004).
\end{tabular}

This work uses an adapted version of the scale proposed by Jantunen et al. (2008) to measure international performance. The general nature of these measurements implies that their applicability should neither differ nor be subject to any influences of the sample characteristics or other variables in the proposed model. On the basis of this scale, INV managers were asked about their degree of satisfaction with the results for the following aspects of their international activity (Table 5).

Table 5: International performance measurement scale



Source: Own work based on Jantunen et al. (2008). 


\subsection{Validity and scale reliability}

A confirmatory factor analysis was done using the structural equation model technique to purge scales. This analysis method ensures a model is consistent with theoretical proposals based on reliable, valid measurement scales, which also have some degree of one dimensionality. The "model development strategy" has been previously used (Hair et al., 2006). Thus, based on the latent variable structures assumed for the different constructs, an improvement process procedure was carried out to perfect the initial models by suppressing the least appropriate indicators.

In line with this, we firstly examined the estimation parameters by taking Jöreskog and Sörbom's (1993) recommendations as a reference. Those indicators that did not fulfill the strong convergence condition were withdrawn (Steenkamp and Van Trijp, 1991). Strong convergence must be analysed by observing the substantiality of loads. Thus, indicators with standardised coefficients $(\lambda)$ under 0.7 (Hair et al., 2006) were considered non-substantial and could, therefore, be eliminated. Then compliance with the weak convergence condition was verified (Steenkamp and Van Trijp, 1991) by analysing the significance of the factor regression coefficients between indicators and their corresponding latent variables. This was done by revising the Student $t$ value imposing the maximum requirement $(\mathrm{t}>2.58 ; \mathrm{P}=0.01)$. Compliance with this requirement ensures that all the indicators significantly relate to their corresponding latent variable. As a third criterion, which is closely related to the first, those indicators that fulfilled the above criteria, but did not achieve a minimum strength in their corresponding linear relationship, were sequentially eliminated. As the linear relationship is measured through the $\mathrm{R} 2$ observed for each relationship, $\mathrm{R}_{2}$ was required to reach a minimum value of 0.49. Finally, evolution of the main model fit measurements was monitored as indicators were eliminated. By means of this process, indicators DIFCA.3, DIFCA.4 and COSTCA.3 were eliminated from the scales for differentiation and cost-based competitive advantages, and EXCH.3 was eliminated from the network market orientation scale (see Table 6).

Table 6: Summary of the results after the definitive factor analysis

\begin{tabular}{|c|c|c|c|c|c|c|c|c|}
\hline \multirow{2}{*}{ Scale } & \multicolumn{9}{|c|}{ First-order } & $\begin{array}{c}\text { Second- } \\
\text { order }\end{array}$ \\
\cline { 2 - 10 } & DIFCA & COSTCA & PERF & ADAP & COOR & CONF & EXCH & NMO \\
\hline Parameters & $0.71-0.82$ & $0.85-0.86$ & $0.74-0.86$ & $0.81-0.91$ & $0.72-0.84$ & $0.73-0.89$ & $0.72-0.87$ & $0.76-0.95$ \\
\hline \multicolumn{3}{|c|}{ Significant loads } & All t $>2.58$. & & $\mathbf{R}^{2}$ & \multicolumn{4}{c|}{ All R ${ }^{2}>0.49$} \\
\hline$\chi^{2} /$ df & RMSEA & SRMR & GFI & AGFI & NFI & NNFI & IFI & CFI \\
\hline 1.726 & 0.049 & 0.050 & 0.894 & 0.864 & 0.901 & 0.947 & 0.956 & 0.955 \\
\hline
\end{tabular}

Then several tests were run to verify whether the purging process had harmed scale reliability after the above tests had been performed. One of the most common reliability measurements is internal consistency, applied to the consistency between variables in an additive scale (Churchill, 1979; Nunnally, 1979). One measurement type for assessing internal consistency is the reliability coefficient, which assesses the consistency of the entire scale, while Cronbach's alpha (Nunnally, 1979) is the most widely used measure. Other complementary reliability tests were also carried out: composed reliability of the construct and analysis of variance extracted (Table 7).

Table 7: Results of the measurement model reliability analysis

\begin{tabular}{|c|c|c|c|c|c|c|c|c|}
\hline \multirow{2}{*}{ Reliability measurements } & \multicolumn{9}{|c|}{ First-order } & $\begin{array}{c}\text { Second- } \\
\text { order }\end{array}$ \\
\cline { 2 - 11 } & DIFCA & COSTCA & PERF & ADAP & COOR & CONF & EXCH & NMO \\
\hline Initial alpha & 0.690 & 0.717 & 0.887 & 0.845 & 0.871 & 0.887 & 0.687 & NP \\
\hline Alpha after confirmatory & 0.732 & 0.841 & 0.887 & 0.845 & 0.871 & 0.887 & 0.847 & NP \\
\hline Composed reliability & 0.738 & 0.842 & 0.887 & 0.850 & 0.876 & 0.891 & 0.857 & 0.915 \\
\hline Variance extracted & 0.586 & 0.727 & 0.612 & 0.741 & 0.704 & 0.732 & 0.667 & 0.731 \\
\hline
\end{tabular}

Finally, validity of scale content and concept was analysed. The only argument for content validity was that all the scale items were based on a review of the relevant literature to ensure that they responded to the conceptual definition and reflected all the relevant dimensions. 
Then two approaches were followed to analyse concept validity: convergent validity and discriminant validity. Convergent validity was verified by returning to the confirmatory factor analysis done at the start of the process, and by observing the estimated value and significance of the correlations between the dimensions in both scales. These correlations were relatively high and significant, therefore offering sufficient guarantee of convergent validity. Discriminant validity was confirmed using the confidence interval test, which consisted in verifying that value "1" did not appear in the estimated confidence intervals for the correlations between each pair of dimensions (Table 8).

Table 8: Discriminant validity analysis using the confidence interval (CI) test

\begin{tabular}{|c|c|c|c|c|c|c|}
\hline $\begin{array}{c}\text { Pair of } \\
\text { variables }\end{array}$ & DIFCA & DIFCA & DIFCA & COSTCA & COSTCA & PERF \\
PERF & NMO & NMO & NMO \\
\hline CI & {$[0.145 ; 0.421]$} & {$[0.154 ; 0.418]$} & {$[0.036 ; 0.312]$} & {$[0.117 ; 0.369]$} & {$[0.124 ; 0.376]$} & {$[0.279 ; 0.503]$} \\
\hline
\end{tabular}

At this point, we can state that the proposed measurement model is reliable and valid for testing the hypotheses put forward a posteriori (Figure 3).

Figure 3: Model of effects of network market orientation on INVs' international performance

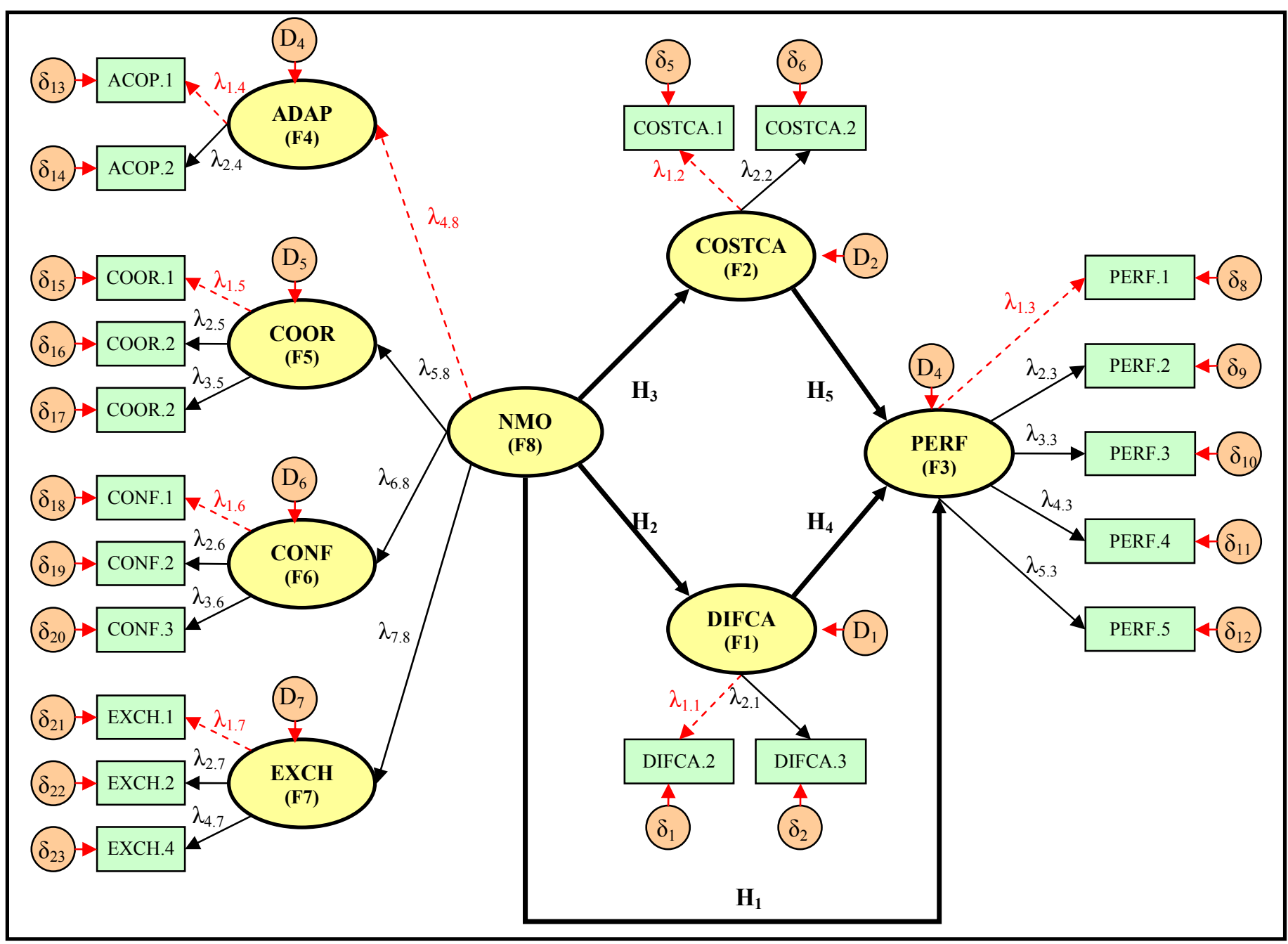

\subsection{Control variables}

Extrapolation from respondents to non-respondents is problematic due to the non-response bias. Gendall (2000) and Wright and Armstrong (2008) state that one of the most effective and reliable factors for minimising the non-response bias is to obtain a high response rate. Another way to ensure that the probability of an incurring non-response is low is to compare the responses of early and late respondents (Armstrong and Overton, 1977). The early versus late method of testing for a non- 
response bias is based on the premise that early respondents accurately represent the average respondent, while late respondents accurately represent the average non-respondent. A t-test of independent means was performed on the different dimensions of the variables in the proposed model. This test was conducted using the first 45 respondents and the last 45 respondents. No significant differences were found between these respondents at the 0.05 level, indicating an absence of a nonresponse bias (Armstrong and Overton, 1977).

In addition, other factors may influence the proposed relationship model and must, therefore, be considered to ensure that they do not affect the results. Thus, various ANOVAs were run to confirm that the sample characteristics did not affect the model constructs. The control variables were sector, international consolidation, firm's age, length of time as an international venture, firm's size, seniority in the firm's main network and network size (Table 9).

Table 9: Results of the ANOVAs for control variables

\begin{tabular}{|c|c|c|c|c|c|c|c|c|}
\hline \multirow{2}{*}{ Control variable } & \multirow{2}{*}{ ANOVA } & \multicolumn{9}{|c|}{ First-order factor } \\
\cline { 3 - 9 } & & DIFCA & COSTCA & PERF & ADAP & COOR & CONF & EXCH \\
\hline \multirow{2}{*}{ Activity sector } & $\mathrm{F}$ & 0.047 & 0.644 & 1.081 & 2.119 & 1.767 & 0.904 & 1.735 \\
\cline { 2 - 9 } & Sig. & 0.954 & 0.527 & 0.343 & 0.126 & 0.139 & 0.464 & 0.140 \\
\hline \multirow{2}{*}{ International consolidation } & $\mathrm{F}$ & 1.320 & 1.566 & 0.616 & 0.873 & 0.391 & 0.400 & 0.618 \\
\cline { 2 - 9 } & Sig. & 0.165 & 0.058 & 0.956 & 0.685 & 0.999 & 0.999 & 0.955 \\
\hline \multirow{2}{*}{ Firm's age } & $\mathrm{F}$ & 0.499 & 1.286 & 0.643 & 1.214 & 1.120 & 1.520 & 1.169 \\
\cline { 2 - 9 } & $\mathrm{Sig}$. & 0.808 & 0.271 & 0.696 & 0.306 & 0.349 & 0.140 & 0.315 \\
\hline \multirow{2}{*}{ International seniority } & $\mathrm{F}$ & 0.664 & 0.472 & 1.272 & 1.701 & 1.387 & 1.669 & 1.676 \\
\cline { 2 - 9 } & $\mathrm{Sig}$. & 0.739 & 0.890 & 0.236 & 0.100 & 0.206 & 0.108 & 0.106 \\
\hline \multirow{2}{*}{ Firm's size } & $\mathrm{F}$ & 0.888 & 0.979 & 0.999 & 0.811 & 0.638 & 0.874 & 0.671 \\
\cline { 2 - 9 } & $\mathrm{Sig}$. & 0.661 & 0.529 & 0.499 & 0.768 & 0.942 & 0.681 & 0.918 \\
\hline \multirow{2}{*}{ Seniority in the network } & $\mathrm{F}$ & 0.878 & 1.020 & 1.634 & 1.444 & 0.338 & 0.700 & 1.260 \\
\cline { 2 - 9 } & $\mathrm{Sig}$. & 0.567 & 0.443 & 0.119 & 0.184 & 0.973 & 0.732 & 0.276 \\
\hline \multirow{2}{*}{ Network size } & $\mathrm{F}$ & 1.080 & 0.817 & 0.753 & 0.535 & 0.677 & 0.888 & 0.683 \\
\cline { 2 - 9 } & Sig. & 0.398 & 0.623 & 0.683 & 0.869 & 0.752 & 0.558 & 0.747 \\
\hline
\end{tabular}

Notes were made as to whether the firm operated in an industrial, commercial or service sector. International consolidation was measured as the percentage of activity carried out abroad since internationalisation. The percentage of activity carried out abroad was calculated by taking into account the following activities in the firm's value chain: manufacture, $R \& D$, commercialisation, advertising and promotion, and after-sales service. The firm's age was calculated based on the difference between the present year and the date the firm was founded. International seniority was measured as the time a firm had been operating at the international level. Firm's size was based on the number of employees. Seniority in the main network was measured by the years that had elapsed since the firm joined the network. Network size was determined by the number of agents in the network.

The influence of all these control variables was studied by measuring each first-order factor in the model, calculated from the items obtained for each one after purging the scales. Table 9 shows that there were no significant differences in any of the analyses.

\subsection{Common method variance bias}

The process for collecting information during the fieldwork involved collecting data for each variable and from the same informer at the same time. This procedure can lead to a possible bias-based problem, normally known in the literature as the "common method variance bias".

This possibility was tested using Harman's (1976) test for a factor which assumes that if this bias existed on the basis of a factor analysis, then a single factor should accumulate the greatest share of covariances of the independent and dependent variables (Podsakoff and Organ, 1986). In line with this, and as Podsakoff et al. (2003) recommend, a factor analysis was run on 20 indicators resulting from the scale purging process using a main components analysis (Velicer and Jackson, 1990), where the factorial solution was examined without rotation.

The factor analysis results reveal that there were seven factors with eigenvalues over 1 . These factors explained $72.550 \%$ of the variance between 20 items and the first of the factors accumulated $31.888 \%$. 
Thus, as several factors were identified and the first of them did not accumulate the greatest share of variance, a substantial part of the common method variance bias did not appear to be present (Friedrich, Byrne and Mumford, 2009; Podsakoff et al., 2003). Therefore, it can be concluded that the bias caused by the method used is not a problem for the validity of the results obtained in the subsequent testing of the hypotheses. However, it should be remembered that this criterion is simply a diagnostic technique (Podsakoff et al., 2003), so the presence of these problems cannot be completely rejected.

\section{Results}

As with the scales validation, the hypotheses were tested by considering structural equations models. These models have proved useful when research aimed to know the causal contributions from one variable to another in a non-experimental situation (Jöreskog and Sörbom, 1993). Furthermore, and unlike techniques such as multiple regression, factor analysis, multivariant analysis of variance etc., which only permit the examination of one relationship at the same time, a structural equations model (SEM)-based analysis is able to explore a series of dependent relations simultaneously (Hair et al., 2006). Therefore, this technique is particularly useful when a dependent variable becomes an independent variable in subsequent dependency relations. This set of relationships, each with dependent and independent variables, is the basis of the SEM.

The hypotheses for the proposed model were tested with the EQS 6.1 software and the results are shown in Table 10. All the hypotheses were accepted. Therefore, network market orientation had a positive and significant effect on INV's international results both directly $\left(\mathrm{H}_{1}: \lambda=0,362 ; \mathrm{t}=4,844\right)$ and indirectly through its influence on achieving differentiation-based and cost-based competitive advantages $\left(\mathrm{H}_{2}: \lambda=0.175 ; \mathrm{t}=2.221\right.$ and $\left.\mathrm{H}_{4}: \lambda=0.194 ; \mathrm{t}=2.675\right)$ and costs $\left(\mathrm{H}_{3}: \lambda=0.290 ; \mathrm{t}=3.556\right.$ and $\left.\mathrm{H}_{5}: \lambda=0.110 ; \mathrm{t}=2.986\right)$.

Table 10: Results of the standardised parameter estimation for the effects model

\begin{tabular}{|c|c|c|c|c|c|c|c|c|}
\hline \multicolumn{5}{|c|}{ Relation } & Load & $\mathbf{t}$ & Hypothesis & Result \\
\hline \multicolumn{5}{|c|}{ NMO $\rightarrow$ INV's international performance } & 0,362 & $4,844 * * *$ & $\mathrm{H}_{1}$ & Not rejected \\
\hline \multicolumn{5}{|c|}{ NMO $\rightarrow$ INV's differentiation CA } & 0,175 & $2,221^{*}$ & $\mathrm{H}_{2}$ & Not rejected \\
\hline \multicolumn{5}{|c|}{ NMO $\rightarrow$ INV's costs CA } & 0,290 & $3,556^{* * *}$ & $\mathrm{H}_{3}$ & Not rejected \\
\hline \multicolumn{5}{|c|}{ INV's differentiation CA $\rightarrow$ INV's international performance } & 0,194 & $2,675 * *$ & $\mathrm{H}_{4}$ & Not rejected \\
\hline \multicolumn{5}{|c|}{ INV's costs $C A \rightarrow$ INV's international performance } & 0,110 & $2,986 * *$ & $\mathrm{H}_{5}$ & Not rejected \\
\hline \multicolumn{9}{|c|}{ Goodness-of-fit indicators } \\
\hline$\overline{X^{2} / g}$ & RMSEA & SRMR & GFI & AGFI & NFI & NNFI & IFI & CFI \\
\hline 1.765 & 0.050 & 0.041 & 0.912 & 0.885 & 0.925 & 0.960 & 0.966 & 0.966 \\
\hline
\end{tabular}

$* *$ Note: $* p<0001 * * p<0.01 * * * p<0.05$.

\section{Discussion and main conclusions}

This research work has been motivated by works on international entrepreneurship appearing in the literature, which acknowledge the growing contribution of INVs to the economic and social progress of globalised economies (Hessels and Van Stel, 2007; Oviatt and McDougall, 2005; Rialp, Rialp and Knight, 2005; Zahra and George, 2002). By bearing certain theoretical trends in mind which defend the relevance of not only market knowledge management (Acedo and Jones, 2007; Autio, Sapienza and Almeida, 2000; Brennan and Garvey, 2009; Casillas et al., 2009; Gassman and Keupp, 2007; Jantunen et al., 2008; Knight and Cavusgil, 2004; Nordman and Melen, 2008; Perks and Hughes, 2008; Sapienza et al., 2006; Weerawardena et al., 2007; Zhou, 2007), but also the relations formed with other agents thanks to belonging to networks of firms (Blomstermo, Eriksson and Sharma, 2004; Chetty and Blankenburg, 2000; Coviello, 2006; Gabrielsson et al., 2008; Johanson and Vahlne, 2009; Loane and Bell, 2006; Morgan, Kaleka and Katsikeas, 2004; Ojala, 2009; Perks and Hughes, 2008; Sharma and Blomstermo, 2003), this work has analysed the influence that the network market orientation in which these firms participate has on their international results.

Specifically, this research empirically demonstrates that knowledge generated from network market orientation makes managing the construction, definition, access, organisation, exchange and use of 
knowledge assets possible in all their forms not only in the firm's individual domain, but also among the various agents making up its network, and that it becomes a fundamental factor in achieving superior results in international markets. This influence is produced both directly and indirectly through firms generating differentiation-based and cost-based competitive advantages.

Firstly, our results complement other works such as that of Morgan, Kaleka and Katsikeas (2004) where the authors centred, be it individually, on the direct influence of the two essential performances that define network market orientation (relating to information and belonging to networks) on achieving superior results. Thus, Morgan, Kaleka and Katsikeas (2004) consider that promoting information-related performances (information about customers, competitors, channels and overseas domains) helps reduce the uncertainty associated with selling products in overseas markets (Katsikeas and Morgan, 1994; Souchon and Diamantopoulos, 1996). Likewise, the performances which encourage relations with network members enable a better understanding and response to challenges deriving from overseas markets (Bello, Urban and Verhage, 1991; Rosenbloom and Larsen, 1992). Both performances will affect the effectiveness and efficacy of the firm's actions in its target market (Morgan, Kaleka and Katsikeas, 2004) and, therefore, its results. In this sense, our work completes this individual vision as it includes the essence of both performances and their effect on the results in a network market orientation construct.

Furthermore, our study demonstrates that the influence of network market orientation on INVs' international results also arises indirectly through the competitive advantages that INVs accomplish. Thanks to adopting network market orientation and to establishing the relational knowledge creation, search and diffusion mechanisms that it entails, it is possible to increase the speed of firms' transmissions and responses, to encourage the development of multidirectional information flows, technical collaboration and relational cooperation (Ling-yee and Ogunmokun, 2001), and to help store and exchange valuable knowledge (Demarest, 1997; Hasen, Nohria and Tierney, 1999; Duffy, 2000; Nonaka and Takeuchi, 1995; Nonaka, Umemoto and Senoo, 1996). These circumstances provide the firm with key information when it undertakes its actions and develops its offer, thus facilitating firms' differential character and improving their capacity to undertake and introduce such actions at a lower cost than their rivals.

For this reason, INVs must reinforce their conviction that managing relational strategy processes offers them lots of opportunities to accomplish better results (Day, 2000; Day and Van den Bulte, 2002; Dyer and Singh, 1998; Hogan and Amstrong, 2001; Hyvönen and Tuominen, 2007; Martin and Grbac, 2003; Morgan and Hunt, 1999; Simpson, Siguaw and Baker, 2001; Spekman, Spear and Kamauff, 2002; Srivastava, Fahey and Christensen, 2001; Sudharshan and Sánchez, 1998). In fact, Srivastava, Shervani and Fahey (1998) previously stressed the notion that the best products were not those that necessarily triumph, whereas better related firms tend to triumph. In this way, market-based relational factors can help the firm create a superior value than that which the firm could generate if acting on its own (Hyvönen and Tuominen, 2007). Hence in light of the results obtained, we can conclude that INVs face the need to develop knowledge management systems or mechanisms in the areas where they perform which enable the use of the knowledge generated so that they can make good use of the market opportunities that come their way and, thus, improve their results.

\section{Managerial implications}

INVs are destined to become the companies of the 21st century. For Hessels and Van Stel (2007) this belief is due to the significant contribution of such firms to economic and social progress in globalized economies. One of the main issues to catch the attention of many IE researchers is analysis of the key factors that enable these firms and their managers to develop sustainable competitive advantages in international markets from their beginnings (Jones, Coviello and Tang, 2011). This work has explored the role of network market orientation as an exclusive asset that can help INVs to develop sustainable competitive advantages and obtain superior levels of performance.

In this regard, we have shown that knowledge of foreign markets plays an important role in explaining the internationalisation of INVs as it constitutes a key variable in their proactive search for 
international opportunities (Autio, Sapienza and Almeida, 2000; Eriksson, Majkgard and Sharma, 2000; Johanson and Vahlne, 2009; Knight and Cavusgil, 2004; Loane and Bell, 2006; Weerawardena et al., 2007). Our results highlight the importance for managers of developing joint market orientation in the INV network. The processes of information exchange, coordination, adaptation and conflict resolution established in coordination by firms in the INV network not only provide them with information on the characteristics of their competitive environment, but also positively influences their ability to assimilate and use that information.

Therefore managers have to consider that network market orientation is a key element for understanding the network's capacity as an incentive to learning in INVs. In fact, agreements established between firms in the network are usually inherently incomplete contracts in which the property rights associated with alliance output and profits may not be well defined. As a result, collaborators risk opportunistic exploitation from partners, including leaking proprietary knowledge to other partners or otherwise losing control of important assets (Hamel, 1991; Williamson, 1991). Although appropriate use of governance structures might ameliorate these concerns (Larson, 1991; Oxley, 1997), intra-alliance rivalry retains the potential to severely disrupt an alliance and to harm a participating firm. This is particularly true when alliances are at risk of deteriorating into learning races (Khanna et al., 1998) in which a firm attempts to extract as much knowledge as possible from its partner while divulging as little as possible. The processes of adaptation and conflict resolution that firms in the network establish help to reduce these harmful effects that limit the network's ability as an antecedent to organizational learning processes.

In sum the results of our study show managers that in INVs the development of strategic relational processes such as network market orientation provides them with many opportunities to improve results (Day and Van den Bulte, 2002; Martin and Grbac, 2003; Spekman, Spear and Kamauff, 2002; Srivastava, Fahey and Christensen, 2001). Network market orientation can help INVs to create higher value than they could generate on their own (Hyvönen and Tuominen, 2007). Thus network market orientation is identified as a key variable in furthering understanding of how knowledge dispersed in several organisations can be consolidated as an essential element for INV sustainability in foreign markets. We have confirmed that market information and the processes by which INVs develop market knowledge are essential for understanding their international performance (Autio, Sapienza and Almeida, 2000; Oviatt and McDougall, 2005; Weerawardena et al., 2007; Zahra, 2005; Zahra, Ireland and Hitt, 2000). As Weerawardena et al., (2007) suggest, this knowledge can be developed through different complementary sources, such as personal networks, the founder's experience, etc. In this paper we do not attempt to analyze all the sources from which INVs can derive this market knowledge, but rather we have focused on the role of INV networks.

\section{Limitations and future research lines}

The present work is not without its limitations, which should be taken into account when assessing the above conclusions. These limitations have led us to consider possible future research lines.

Firstly, we identify a series of theoretical limitations; our model is a specific contribution that can be used to propose new effects by considering new factors. In fact, we are well aware that our model does not contemplate all the variables that can explain competitiveness and the international results of new ventures; thus, future works could investigate this issue.

In this sense, taking into account that this works represents a complementation to previous works focused on determining the effects of individual factors, such as market orientation, on the competitiveness of INVs future studies could analyze the relationship between both individual and network factors, that is, between network and firm market orientations.

The market orientation of the INV network helps INVs to have and use privileged information on international markets. It is expected that use of information on international markets generated from networks can increase the efficiency and efficacy of the main internationalisation decisions that INVs face when identifying and developing business opportunities in international markets. Oviatt and McDougall (2005) point out that these decisions are related to not only the speed with which an INV's 
presence increases in existing markets, but also to the speed with which it enters new markets. Furthermore, given that the entry methods choice is a critical decision for INVs (Autio 2005; Zahra 2005), we also propose studying the impact of network market orientation on different entry modes.

By focusing on the selection of the study sample, opting only for INVs in Spain limits the possibility of generalising the results to other international contexts. By taking this limitation into account, new studies could examine the relations proposed in other national contexts to test the results reported here. Similarly, our proposed model, based on a multi-sector sample, can implies a limitation when assuming that all the networks are the same in structure, in behaviour and so in results. Then our study could serve as reference for other studies to focus on specific sectors and industries, where networks and firms present higher possibilities of homogeneity.

A third limitation is that our empirical study is based on the responses of a single interviewee for each company and network in our sample. This fact raises three issues: firstly, the question of whether a single interviewee can respond adequately on behalf of an entire organisation; secondly, our survey addresses managers of a single company who responded about how a network of firms operates as a whole; thirdly, the fact that the fieldwork was done using an online questionnaire can make us wonder who actually answered the questionnaire.

As a final limitation, use of cross-sectional data, as in this case, can be considered a limitation when making causal inferences. Therefore, future studies could study the considered relations by employing longitudinal data.

\section{References}

Acedo, F. J. and Jones, M. V. (2007) 'Speed of internationalization and entrepreneurial cognition: Insights and a comparison between international new ventures, exporters and domestic firms', Journal of World Business, Vol. 42 , pp. 236-252.

Anderson, J.C., Häkansson, H. and Johanson, J. (1994) 'Dyadic business relationships within a business network context', Journal of Marketing, Vol. 58 (October), pp. 1-15.

Armstrong, J.S. and Overton, T.S. (1977) 'Estimating non-response bias in mail surveys', Journal of Marketing Research, Vol. 16 (August), 396-402.

Aspelund, A., Madsen, T.K. and Moen, Ø. (2007) 'International new ventures: A review of conceptualizations and findings', European Journal of Marketing, Vol. 41 No. 11/12, pp. 1423-1474.

Autio, A. (2005) 'Creative tension: The significance of Ben Oviatt's and Patricia McDougall's article 'toward a theory of international new ventures', Journal of International Business Studies, Vol. 36 No. 1, pp. 9-19.

Autio, E., Sapienza, H. J. and Almeida, J.G. (2000) 'Effects of age at entry, knowledge intensity, and imitability on international growth', Academy of Management Journal, Vol. 43, pp. 909-924.

Baker, W.E. and Sinkula, J.M. (2005) 'Market Orientation and the New Product Paradox', Journal of Product Innovation Management, Vol. 22 No. 6, pp. 483-502.

Barney, J. B. (1991) 'Firm Resources and Sustained Competitive Advantage', Journal of Management, Vol. 17 No. 1, pp. 99.

Bello, D.C., Urban, D.J. and Verhage, B.J. (1991) 'Evaluating export middlemen in alternative channel structures', International Marketing Review, Vol. 8, pp. 49-64.

Beverland, M.B. and Lindgreen, A. (2007) 'Implementing market orientation in industrial firms: A multiple case study', Industrial Marketing Management, Vol. 36 No.4, pp. 430-442.

Bhuian, S. N., Menguc, B. and Bell, S. J. (2005) 'Just entrepreneurial enough: the moderating effect of entrepreneurship on the relationship between market orientation and performance', Journal of Business Research, Vol. 58, pp. 9-17.

Blomstermo, A., Eriksson, K. and Sharma, D.D. (2004) 'Domestic activity and knowledge development in the internationalization process of firms', Journal of International Entrepreneurship, Vol. 2, pp. 239-258.

Borgatti, S.P. and Foster, P. (2003). 'The network paradigm in organizational research: A review and typology', Journal of Management, Vol. 29 No. 6, pp. 991-1013. 
Bouncken, R.B. (2003) 'Impact of Network Collaboration Mode on the Degree of Novelty of Innovation'. Annual Conference of the Strategic Management Society, Baltimore.

Brennan, L. and Garvey, D. (2009) 'The role of knowledge in internationalization', Research in International Business and Finance, Vol. 23 No. 2, pp. 120-133.

Burgel, O. and Murray, G.C. (2000) 'The International Market Entry Choice of Start-Up Companies in HighTechnology Industries', Journal of International Marketing, Vol. 8 No. 2, pp. 33-62.

Cadogan, J. W., Cui, C.C. and Yeung Li, E.K. (2003) 'Export Market-oriented Behavior and Export Performance: The Moderating Roles of Competitive Intensity and Technological Turbulence', International Marketing Review, Vol. 20 No. 5, pp. 493-513.

Cano, C. R., Carrillat, F. A. and Jaramillo, F. (2004) 'A meta-analysis of the relationship between market orientation and business performance: evidence from five continents', International Journal of Research in Marketing, Vol. 21 No. 3, pp. 179-200.

Casillas, J.C., Moreno, A.M., Acedo, F.J. and Gallego, M.A. (2009) 'An integrative model of the role of knowledge in the internationalization process', Journal of World Business, Vol. 44 No. 3, pp. 311-322.

Cavusgil, S.T. and Zou, S. (1994) 'Marketing strategy-performance relationship: an investigation of the empirical link in export market venture', Journal of Marketing, Vol. 58 No. 1, pp. 1-21.

Chen, Y. S., Lin, M. J. J. and Chang, C. H. (2009) 'The positive effects of relationship learning and absorptive capacity on innovation performance and competitive advantage in industrial markets', Industrial Marketing Management, Vol. 38, pp. 152-158.

Chetty, S., D. and BlankenburG H. (2000) 'Internationalisation of small to medium-sized manufacturing firms: a network approach’, International Business Review, Vol. 9 No. 1, pp. 77-93.

Chung, J., Jin, B. and Sternquist, B. (2007) 'The role of market orientation in channel relationships when channel power is imbalanced', The International Review of Retail, Distribution and Consumer Research, Vol. 17 No. 2, pp. 159-176.

Churchill, G.A.Jr. (1979) 'A Paradigm for Developing Better Measures in Marketing', Journal of Marketing Research, Vol. 16, pp. 64-73.

Coviello, N. E. (2006) 'The network dynamics of international new ventures', Journal of International Business Studies, Vol. 37 No. 5, pp. 713-731.

Day, G. S. (2000) 'Managing market relationships’, Academy of Marketing Science, Vol. 28 No. 1, pp. 24-30.

Day, G. S. and Van Den Bulte, C. (2002) 'Superiority in Customer Relationship Management: Consequences for Competitive Advantage and Performance'. Report No. 02-123. Cambridge, MA: Marketing Science Institute.

Day, G. S. and Wensley, R. (1988) 'Assessing Advantage: A Framework for Diagnosing Competitive Superiority', Journal of Marketing, Vol. 52 (April), pp. 1-20.

Demarest, M. (1997) 'Understanding knowledge management', Long Range Planning, Vol. 30, pp. 374-384.

Duffy, J. (2000) 'The KM technology infrastructure', Information Management Journal, Vol. 34 No. 2, pp. 6266.

Dyer, J. and Singh, H. (1998) 'The relational view: cooperative strategy and sources of interorganizational competitive strategy’, Academy of Management Review, Vol. 23, pp. 660-679.

Elg, U. (2002) 'Inter-firm market orientation: Its significance and antecedents in distribution networks', Journal of Marketing Management, Vol. 18 No. 7/8, pp. 633-656.

Elg U. (2003) 'Retail market orientation: a preliminary framework', International Journal of Retail \& Distribution Management, Vol. 31 No. 2, pp. 107-117.

Elg, U. (2007) 'Market orientation as inter-firm cooperation: an international study of the grocery sector', European Journal of Management, Vol. 4, pp. 283-297.

Ellis, P. (2006) 'Market orientation and performance: A meta-analysis and cross-national comparisons', Journal of Management Studies, Vol. 43 No. 5, pp. 1089-1107.

Eriksson, K., Majkgard, A. and Sharma, D. (2000) 'Path dependence and knowledge development in the internationalization process', Management International Review, Vol. 40, pp. 307-328. 
Etemad, H. (2003) 'Managing relations: The essence of international entrepreneurship'. In: H. Etemad y R. Wright (eds.), Globalization and entrepreneurship: Policy and strategy perspectives. Northampton, MA: Edward Elgar, pp. 223-243.

Evanschitzky, H. (2007) 'Market orientation of service networks: Direct and indirect effects on sustained competitive advantage', Journal of Strategic Marketing, Vol. 15, pp. 349-368.

Friedrich, T.L., Byrne, C.L. and Mumford, M.D. (2009) 'Methodological and theoretical considerations in survey research', The Leadership Quarterly, Vol. 20, pp. 57-60.

Gabrielsson, M., Kirpalani, V. H. M., Dimitratos, P., Solberg, C. A. and Zucchella, A. (2008) 'Born Globals: Propositions to Help Advance the Theory', International Business Review, Vol. 17 No. 4, pp. 385-401.

Gassmann, O. and Keupp, M. M. (2007) 'The competitive advantage of early and rapidly internationalizing in the biotechnology industry: A knowledge-based view', Journal of World Business, Vol. 42, pp. 350-366.

Gendall, P. (2000) 'Responding to the problem of nonresponse', Australasian J. Marketing Res., Vol. 8 No. 1, pp. 3-18.

Gilmore, A., Carson, D. and Rocks, S. (2006) 'Networking in SMEs: Evaluating its Contribution to Marketing Activity’, International Business Review, Vol. 15, pp. 278-293.

Grant, R. M. (1996) 'Toward a Knowledge-Based Theory of the Firm', Strategic Management Journal, Vol. 17, pp. 109-122.

Grinstein, A. (2008) 'The relationships between market orientation and alternative strategic orientations: A metaanalysis'. European Journal of Marketing, Vol. 42 No. 1/2, pp. 115-134.

Ha-Brookshire, J.A. and Dyer, B. (2009) 'The Impact of Firm Capabilities and Competitive Advantages on Import Intermediary Performance', Journal of Global Marketing, Vol. 22 No. 1, pp. 5-19.

Hair, J.F., Black, W.C., Babin, B.J., Anderson, R.E., and Tatham, R.L. (2006) 'Multivariate data analysis' (6th ed.). Upper Saddle River, N.J.: Pearson Education Inc.

Hamel, G. (1991) 'Cornpetition for cornpetcnce and inter-partner learning within international strategic alliances', Strategic Management Journal, Vol. 12, pp. 83-104.

Han, J.K., Kim, N. and Srivastava, R.K. (1998) 'Market Orientation and Organizational Performance: Is Innovation a Missing Link?', Journal of Marketing, Vol. 62 (October), pp. 30-45.

Harker, M. (1999) 'Relationship Marketing defined? An Examination of Current Marketing Definitions', Marketing Intelligence and Planning, Vol. 17 No. 1, pp. 13-20.

Harman, H.H. (1976) 'Modern Factor Analysis’. Third Edition. Chicago: The University of Chicago Press.

Hasen, M.T., Nohria, N. and Tierney, T. (1999) 'What's Your Strategy for Managing Knowledge', Harvard Business Review, (March-April), pp. 110-116.

Helfert, G., Ritter, T. and Walter, A. (2002) 'Redefining market orientation from a relationship perspective. Theoretical considerations and empirical results', European Journal of Marketing, Vol. 36 No. 9/10, pp. 11191139.

Hessels, J. and Van Stel, A. (2007) 'Export Orientation Among New Ventures and Economic Growth' (26 2007, 01). ERIM Report Series Reference No. ERS-2007-008-ORG. http://ssrn.com/abstract=962253

Hite, J. and Hesterly, W. (2001) 'The evolution of firm networks: From emergence to early growth of the firm', Strategic Management Journal, Vol. 22, pp. 275-286.

Hogan J.E. and Armstrong, G. (2001) 'Toward a resource-based theory of business exchange relationships: the role of relational asset value', Journal of Business-to-Business Marketing, Vol. 8 No. 4, pp.3-28.

Hult, G.T.M. and Ketchen, D.J. (2001) 'Does Market Orientation Matter? A Test of the Relationship Between Positional Advantage and Performance’, Strategic Management Journal, Vol. 22 No. 9, pp. 899-906.

Hunt, S. D. (2000) A general theory of competition: Resources, competences, productivity, economic growth. Thousand Oaks, CA: Sage.

Hunt, S. D. and Lambe, C. J. (2000) 'Marketing's contribution to business strategy: market orientation, relationship marketing and resource-advantage theory', International Journal of Management Reviews, Vol. 2 No. 10, pp. 17-43. 
Hyvonen, S. and Tuominen, M. (2007) 'Hyvonen and Tuominen, Channel collaboration, market orientation and performance advantages: Discovering developed and emerging markets', The International Review of Retail, Distribution and Consumer Research, Vol. 17 No. 5, pp. 423-445.

Jantunen, A., Nummela, N., Puumalinen, K. and Saarenketo, S. (2008) 'Strategic orientation of born globals - do they really matter?', Journal of World Business, Vol. 43 No. 2, pp. 158-70.

Jarratt, D. G. (2004) 'Conceptualizing a Relationship Management Capability', Marketing Theory, Vol. 4, pp. 287-309.

Johanson, J. and Vahlne, J. E. (1977) 'The internationalization process of the firm: a model of knowledge development and increasing foreign market commitment', Journal of International Business Studies, Vol. 8 No. 1, pp. 23-32.

Johanson, J. and Vahlne, J. E. (2009) 'The Uppsala internationalization process model revisited: From liability of foreignness to liability of outsidership', Journal of International Business Studies, Vol. 40, pp. 1411-1431.

Johnson, J.L. and Sohi, R.S. (2003) 'The development of interfirm partnering competence: platforms for learning, learning activities, and consequences of learning', Journal of Business Research, Vol. 56, pp. 757-66.

Jones, M.V., Coviello, N. and Tang Y.K. (2011) 'International Entrepreneurship research (1989-2009): A domain ontology and thematic analysis', Journal of Business Venturing, Vol. 26, pp. 632-659.

Jöreskog, K. and Söbom, D. (1993) 'LISREL 8: structural equation modeling with the SIMPLIS command language’. Scientific Software International, Chicago, Illinois.

Karlsson, C. (2003). 'The development of industrial networks: Challenges to operations management in an extraprise', International Journal of Operations \& Production Management, Vol. 23 No. 1, pp. 44-61.

Katsikeas, C. S. (1994) 'Export Competitive Advantages. The Relevance of Firm Characteristics', International Marketing Review, Vol. 11 No. 3, pp. 33-53.

Katsikeas, C. S. and Morgan, R. E. (1994) 'Differences in perceptions of exporting problems based on firm size and export market experience', European Journal of Marketing, Vol. 28 No. 5, pp. 17-35.

Khanna, T., Gulati, R. and Nohria, N. (1998) 'The dynamics of learning alliances: competition, cooperation, and relative scope', Strategic Management Journal, Vol. 19, pp. 193-210.

Kirca, A.H., Jayachandran, S. and Bearden, W.O. (2005) 'Market orientation: a meta-analytic review and assessment of its antecedents and impact on performance', Journal of Marketing, Vol. 69, pp. 24-41.

Kiss, A. N. and Danis, W. M. (2008) 'Country institutional context, social networks, and new venture internationalization speed', European Management Journal, Vol. 26, pp. 388-399.

Knight, G. A. and Cavusgil, T. (2004) 'Innovation, organizational capabilities, and the born-global firm', Journal of International Business Studies, Vol. 35, pp. 124-141.

Knight G. A. and Liesch P. W. (2002) 'Information internalisation in internationalising the firm', Journal of Business Research, Vol. 55, pp. 981-995.

Kohli, A.K. and Jaworski, B.J. (1990) 'Market orientation: the construct, research propositions, and managerial implications', Journal of Marketing, Vol. 54, pp. 1-18.

Kotha, S. and Nair, A. (1995) 'Strategy and environment as determinants of performance: evidence from the Japanese machine tool industry’, Strategic Management Journal, Vol. 16 No. 7, pp. 497-519.

Lado, A.A., Boyd, N. G. and Hanlon, S.C. (1997) 'Competition, cooperation and the search for economic rents: a syncretic model’, Academy of Management Review, Vol. 22 No. 1, pp. 110-141.

Langerak, F. (2001) 'Effects of Market Orientation on the Behaviors of Salespersons and Purchasers, Channel Relationships, and Performance of Manufacturers', International Journal of Research in Marketing, Vol. 18, pp. 221-234.

Langerak, F. (2003) 'An Appraisal of Research on the Predictive Power of Market Orientation', European Management Journal, Vol. 21 No. 4, pp. 447-464.

Langerak, F., Hultink, E.J. and Robben, H.S.J. (2007) 'The mediating role of new product development in the link between market orientation and organizational performance', Journal of Strategic Marketing, Vol. 15 No. 4 , pp. 281-305. 
Larson, A. (1991) 'Partner networks: Leveraging external ties to improve entrepreneurial performance', Journal of Business Venturing, Vol. 6, pp. 173-188.

Li, Y., Liu, Y., DuaN, Y. and Li, M. (2008) 'Entrepreneurial orientation, strategic flexibilities and indigenous firm innovation in transitional China', International Journal of Technology Management, Vol. 41 No. 1/2, pp. 223-246

Liao, S.H., Chang, W.J. and Wu, C.C. (2010) 'An integrated model of learning organization with strategic view: Benchmarking in the knowledge-intensive industry', Expert Systems with Applications, Vol. 37 No. 5, pp. 37928.

Liao, S.H., Chang, W.J., Wu, C.C. and Katrichis J. M. (2011) 'A survey of market orientation research (19952008)'. Industrial Marketing Management, Vol. 40, pp. 301-310.

Liebeskind, J. (1996) 'Knowledge, Strategy, and the Theory of the Firm', Strategic Management Journal, Vol. 17 No. 1, pp. 93-107.

Lin, B.W. and Chen, C.J. (2006) 'Featuring Product Innovation in Industry Networks: The Mediating Role of Knowledge Integration', International Journal of Human Resource Management, Vol. 17 No. 1, pp. $155-173$.

Ling-Yee, L. and Ogunmokun, G. O. (2001) 'The influence of interfirm relational capabilities on export advantage and performance: an empirical analysis', International Business Review, Vol. 10, pp. 399-420.

Loane, S. and Bell, J. (2006) 'Rapid internationalisation among entrepreneurial firms in Australia, Canada, Ireland and New Zealand: An extension to the network approach', International Marketing Review, Vol. 23 No. 5, pp. 467-485.

Martin J.H. and Grbac, B. (2003) 'The effects of supplier focus, customer responsiveness and strategy type on growth in a transition economy', Journal of Marketing, Theory and Practice, Vol. 11 No. 2, pp. 43-55.

Matsuno, K., Mentzer, J. T. and Rentz, J. O. (2004) 'A conceptual and empirical comparison of three market orientation scales', Journal of Business Research, Vol. 58 No. 1, pp. 1-8.

Menguc, B., Auh, S. and Shih, E. (2007) 'Transformational leadership and market orientation: Implications for the implementation of competitive strategies and business unit performance', Journal of Business Research, Vol. 60 No. 4, pp. 314-321.

Meso, P. and Smith, R. (2000) 'A resource-based view of organizational knowledge management system', Journal of Knowledge Management, Vol. 4 No. 13, pp. 224-234.

Mizik, N. and Jacobson, R. (2003) 'Trading Off between Value Creation and Value Appropriation: The Financial Implications of Shifts in Strategic Emphasis', Journal of Marketing, Vol. 67 (January), pp. 63-76.

Moen, O. (1999) 'The Relationship between Firm Size, Competitive Advantages and Export Performance Revisited', International Small Business Journal, Vol. 18 No. 1, pp. 53-72.

Morgan, R. T. and Hunt, S. (1999) 'Relationship-Based Competitive Advantage: The Role of Relationship Marketing in Marketing Strategy’, Journal of Business Research, Vol. 46, pp. 281-290.

Morgan, N., Kaleka, A. and Katsikeas, C. (2004) 'Antecedents of Export Venture Performance: A Theoretical Model and Empirical Assessment', Journal of Marketing, Vol. 68, pp. 90-108.

Noble, C.H., Sinha, R.K. and Kumar, A. (2002) 'Market orientation and alternative strategic orientations: a longitudinal assessment of performance implications', Journal of Marketing, Vol. 6 (October), pp. 25-39.

Nonaka, I. and Takeuchi, H. (1995) 'The Knowledge creating company: how Japanese companies create the dynamics of innovation', Oxford University Press, New York.

Nonaka, I., Umemoto, K. and Senoo, D. (1996) 'From information processing to knowledge creation: A paradigm shift in business management', Technology in Society, Vol. 18 No. 2, pp. 203-218.

Nordman, E.M. and Melen, S. (2008) 'The impact of different kinds of knowledge for the internationalization process of born globals in the biotech business', Journal of World Business, Vol. 43 No. 2, pp. 171-85.

Nunnaly, J. (1979) 'Psychometric Theory’, McGraw-Hill, Nueva York.

O'cass, A. and Ngo, L.V. (2007) 'Market orientation versus innovative culture: Two routes to superior brand performance', European Journal of Marketing, Vol. 41 No. 7/8, pp. 868-887.

Offsey, S. (1997) 'Knowledge management: linking people to knowledge for bottom line results', Journal of Knowledge Management, Vol. 1 No. 2, pp. 113-122. 
Ojala, A. (2009) 'Internationalization of knowledge-intensive SMEs: the role of network relationships in the entry to a psychically distant market', International Business Review, Vol. 18 No. 1, pp. 50-59.

Oviatt, B. M. and McDougall, P. (1994) 'Toward a theory of international new ventures', Journal of International Business Studies, Vol. 25 No. 1, pp. 45-64.

Oviatt, B. M. and McDougall, P. P. (2005) 'Defining international entrepreneurship and modeling the speed of internationalization', Entrepreneurship: Theory and Practice, Vol. 29 No. 5, pp. 537-553.

Oxley, J. E. (1997) 'Appropriability hazards and governance in strategic alliances: A transaction cost approach', Journal of Law, Economics, and Organization, Vol. 13, pp. 387-409.

Penrose, E. (1959) 'The Theory of the Growth of the Firm', Oxford University Press, Oxford.

Perks, K. and Hughes, M. (2008) 'Entrepreneurial decision-making in internationalization: Propositions from mid-size firms', International Business Review, Vol. 17 No. 3, pp. 310-330.

Piercy, N., Kaleka, A. and Katsikeas, C. (1998) 'Souces of Competitive Advantage in Hight Performing Export Company’, Journal of World Business, Vol. 33 No. 4, pp. 378-393.

Podsakoff, P.M., Mackenzie, S.B., Lee, J. and Podsakoff, N. (2003) 'Common method biases in behavioral research: A critical review of the literature and recommended remedies', Journal of Applied Psychology, Vol. 88, pp. 879-903.

Podsakoff, P.M. and Organ, D.W. (1986) 'Self-reports in organizational research: problems and prospects' Journal of Management, Vol. 12 No. 4, pp. 531-44.

Porter, M. E. (1985) 'Competitive Advantage: Creating and Sustaining Superior Performance'. New York: Free Press.

Powell, W.W. and Smith-Doerr, L. (1994). 'Networks and Economic Life'. In Handbook of Economic Sociology, edited by N. Smelser and R. Swedberg. Princeton, NJ: Princeton University Press, pp. 368-402.

Qiu, T. (2008) 'Scanning for competitive intelligence: A managerial perspective', European Journal of Marketing, Vol. 42 No. 8, pp. 814-835.

Racela, O., Chaikittisilpa, C. and Thoumrungroje, A. (2007) 'Market orientation, international business relationships and perceived export performance', International Marketing Review, Vol. 24 No. 2, pp. $144-163$.

Reichheld, F.F. (1993) 'Loyalty-Based Management', Harvard Business Review, Vol. 71 No. 2, pp. 64-71.

Rialp, A., Rialp, J. and Knight, G. (2005) 'The phenomenon of early internationalizing firms: what do we know after a decade (1993-2003) of scientific inquiry?’, International Business Review, Vol. 14 No. 2, pp. 147-166.

Rialp, A.; Rialp, J. and Salas, V. (2002) 'Faster and highly successful exporters: An explanation of born globals firms from the resource-based view', Research in Entrepreneurship and Small Business, 16th. Workshop.

Rosenbloom, B. and Larsen, T.L. (1992) 'How foreign firms view their US distributors', Industrial Marketing Management, Vol. 21 No. 2, pp. 93-101.

Sapienza, H., Autio, E., George, C. and Zahra, S.A. (2006) 'A capabilities perspective on the effects of early internationalization on firm survival and growth', Academy of Management Review, Vol. 31 No. 4, pp. 914-933.

Selnes, F. and Sallis, J. (2003) 'Promoting relationship learning'. Journal of Marketing, Vol. 67 No. 2, pp. 8095.

Sharma, D.D. and Blomstermo, A. (2003) 'The Internationalisation Process of Born Globals: A Network View', International Business Review, Vol. 12, pp. 739-53.

Sher, P.J. and Lee, V.C. (2004) 'Information Technology as a Facilitator for Enhancing Dynamic Capabilities through Knowledge Management', Information \& Management, Vol. 41 No. 8, pp. 933-945.

Shoham, A., Rose, G. M., and Kropp, F. (2005) 'Market orientation and performance: a meta-analysis', Marketing Intelligence \& Planning, Vol. 23, No. 5, pp. 435-454.

Siguaw, J. A., Simpson, P. M. and Baker, T. L. (1999) 'The Influence of Market Orientation on Channel Relationships: A Dyadic Examination'. In: R. Deshpandé, Editor, Developing a Market Orientation, Sage, London, pp. 267-302.

Simpson, P.M., Siguaw, J.A. and Baker, T.L. (2001) 'A model of value creation', Journal of Industrial Marketing Management, Vol. 30, pp. 119-34. 
Sin, L., Tse, A., Yau, O., Chow, R. and Lee, J. (2005) 'Market Orientation, relationship marketing orientation, and business performance: the moderating effects of economic ideology and industry type', J. of International Marketing, Vol. 13 No. 1, pp. 36-57.

Sin , L., Tse, A., Yau , O., Lee, J. and Chow, R. (2002) 'The effect of relationship marketing orientation on business performance in a service-oriented economy', Journal of Services Marketing, Vol. 16 No. 7, pp. 656676.

Snoj, B., Milfelner, B. and Gabrijan, V. (2007) 'An examination of the relationships among market orientation, innovation resources, reputational resources, and company performance in the transitional economy of Slovenia', Canadian Journal of Administrative Sciences, Vol. 24 No. 3, pp. 151-164.

Souchon, A. L. and Diamantopoulos, A. (1996) 'A Conceptual Framework of Export Marketing Information Use: Key Issues and Research Propositions’, Journal of International Marketing, Vol. 4 No. 3, pp. $49-72$.

Spekman, R.E., Spear, J. and Kamauff, J. (2002) 'Supply chain competency: learning as a key component', Supply Chain Management: An International Journal, Vol. 7 No. 1, pp. 41-55.

Srivastava, R. K., Fahey, L. and Christensen, H. K. (2001) 'The resource-based view and marketing: The role of marked-based assets in gaining competitive advantage', Journal of Management, Vol. 27 No. 6, pp. 777-802.

Srivastava, R. K., Shervani, T. A. and Fahey, L. (1998) 'Market-Based Assets and Shareholder Value: A Framework for Analysis', Journal of Marketing, Vol. 62 No. 1, pp. 2-18.

Steenkamp, J.B.E.M. and Van Trijp, H.C.M. (1991) 'The use of lisrel in validating marketing constructs', International Journal of Reesearch in Marketing, Vol. 8 No. 4, pp. 283-299.

Sudharshan D. and Sánchez, R. (1998) 'Distribution equity: creating value through managing knowledge relationships with distribution channels', Journal of Market Focused Management, Vol. 2 No. 3, pp. 309-338.

Tse, A., Sin, L., Yau, O., Lee, J. and Chow, R. (2004) 'A Firm's Role in the Marketplace and the Relative Importance of Market Orientation and Relationship Marketing Orientation', European Journal of Marketing, Vol. 38 No. 9/10, pp. 1158-1172.

Velicer, W. F. and Jackson, D. N. (1990) 'Component analysis versus common factor analysis: Some further observations’, Multivariate Behavioral Research, Vol. 25 No. 1, pp. 97-114.

Weerawardena, J, Sullivan, G., Liesch, P.W. and Knight, G. (2007) 'Conceptualizing accelerated internationalization in the born global firm: A dynamic capabilities perspective', Journal of World Business, Vol. 42, pp. 294-306.

Westhead, P., Wright, M., Ucbasaran, D. and Martin, F. (2001) 'International Market Selection Strategies of Manufacturing and Services Firms', Entrepreneurship Regional Development, Vol. 13, pp. 17-46.

Williamson, O.E. (1991) 'Comparative economic organization: The analysis of discrete structural altematives', Administrative Science Quarterly, Vol. 36, pp. 269-296.

Wright, M. and Armstrong, J. S. (2008) 'The Ombudsman: Verification of Citations: Fawlty Towers of Knowledge?' Interfaces, Vol. 38 No. 2, pp. 125-39.

Zahra, S. A. (2005) 'Entrepreneurial Risk Taking in Family Firms', Family Business Review, Vol.18, pp. 23-40.

Zahra, S. A. and Garvis, D. M. (2000) 'International Corporate Entrepreneurship and Firm Performance: The Moderating Effect of International Environmental Hostility’, Journal of Business Venturing, Vol. 15 No. 5/6, pp. 469-492.

Zahra, S. A. and George, G. (2002) 'Absorptive capacity: A review, reconceptualization, and extension', Academy of Management Review, Vol. 27 No. 2, pp. 185-203.

Zahra, S.A. Ireland, R.D. and Hitt, M.A. (2000) 'International expansion by new venture firms: International diversity, mode of market entry, technological learning and performance', Academy of Management Journal, Vol. 43, pp. 925-950.

Zhou, L. (2007) 'The effects of entrepreneurial proclivity and foreign market knowledge on early internationalization', Journal of World Business, Vol. 42, pp. 281-293.

Zucchella, A., Palamara, G. and Denicolai, S. (2007) 'The drivers of the early internationalization of the firm', Journal of World Business, Vol. 42, pp. 268-270. 